\title{
Oil prices, biofuels production and food security: past trends and future challenges
}

\author{
Hang To • R. Quentin Grafton
}

Received: 11 January 2015 / Accepted: 18 February 2015 / Published online: 10 March 2015

(C) Springer Science+Business Media Dordrecht and International Society for Plant Pathology 2015

\begin{abstract}
Using US and global data we estimate autoregressive models of US and global food prices as a function of oil prices, GDP per capita and biofuels production. Our model results show: (1) biofuels production and crude oil prices have a statistically significant effect on food prices in the US and globally; (2) during the global food price spike in 2008 , increases in US biofuels production and the US crude oil price accounted for 38 and $41 \%$, respectively, of the increase in US food prices; (3) during the global food price spike in 2008 , increases in global biofuels production and the global crude oil price accounted for 19 and $40 \%$, respectively, of the increase in global food prices; (4) an independently projected global oil price to 2040 and a projected annual growth in global biofuels production would increase the global food price index in 2040 by 47 percentage points compared to a reference case of constant biofuels production; (5) an independently projected global oil price to 2040 would increase the global food price by 41 percentage points compared to the reference case where global oil price remains at its 2013 level. In sum, we demonstrate that both higher oil prices and increased biofuels production have raised food prices, and that this has contributed to global poverty and chronic undernourishment.
\end{abstract}

Keywords Oil prices $\cdot$ Biofuels production $\cdot$ Food security

\section{Introduction}

In early 2008, global food prices rose at an unprecedented rate, not witnessed since the food price shocks of the early

H. To $\cdot$ R. Q. Grafton $(\bowtie)$

Crawford School of Public Policy (Bldg 132), The ANU,

Lennox Crossing, Acton, ACT 2601, Australia

e-mail: quentin.grafton@anu.edu.au 1970s (Shaw 2007). A key contributing factor to the rise in food prices has been the growth in first-generation biofuels production whereby crops, such as corn and soybean, that would have otherwise entered the food supply chain, directly or indirectly, became a feedstock in the production of ethanol or biodiesel. The OECD reported that between 2005 and 2007, globally, more than half of the increase in demand of both coarse grains and vegetable oil was the result of their use as a feedstock in biofuels production (OECD 2008).

The demand-supply chain process, or pass through, of higher biofuel prices to increased first-generation biofuels production and, ultimately, increased food prices involves several steps (Elobeid and Tokgöz 2007). First, there is a higher demand for first-generation biofuel feedstocks because of higher fossil fuel prices, biofuels subsidies and fuel mandates which elicits greater supply. This augments biofuels crop production, but is insufficient to prevent a price increase for the biofuel crop. Second, the biofuels supply response results in an increase in the land area devoted to the biofuel crop which means less area is planted for food crops given a, more or less, fixed cultivable land area, such as in the United States (US). This substitution between land for food production and land for biofuels production can be large. Indeed, Hertel et al. (2013) reported that under the 'new policies' scenario, land for biofuels could account for nearly one-fifth of global land use change over the period 2006-2035. Third, reduced plantings of food crops, including biofuel crops that would otherwise have gone into the food chain, contributes to higher food prices for a range of food crops. Fourth, higher food crop prices that are a feedstock for livestock increases the cost of livestock production and lowers either the rate of growth or even the level of livestock production, and also increases livestock and meat prices.

The size of the pass through to higher food prices resulting from higher oil prices or subsidies and fuel mandates for biofuels production depends on multiple factors that change 
over time and place. The greater is the substitution between biofuel crops and food crops and the more constrained are the inputs that are jointly used by biofuel crops and food crops, such as land and water, the bigger will be the effect of biofuels production on food prices (Zilberman et al. 2012). Muller et al. (2008) observed that, globally, there is still land and water available to grow a substantial amount of crops for food and biofuels, but in key food production and demand countries, such as China and India, most of the land and water resources suitable for crop production is already used.

The food price effects for the US of higher biofuels prices are summarised by de Gorter et al. (2013a, p. 83). They note that a one cent per gallon increase in ethanol prices results in a 4 cent per bushel rise in the price of corn and a one cent per gallon increase in biodiesel results in an $\$ 11$ per metric tonne increase in the soybean oil price. Other contributing factors to the higher food prices in 2007-8, in addition to biofuels production, include export bans and a rising rate of food consumption to production (Abbott et al. 2011; Tyner 2013), and rapidly rising oil prices (OECD 2008). Substantial empirical evidence exists that policies intended to promote biofuels production, especially in the OECD, coupled with high energy prices, have: (1) been instrumental in raising food prices over the past decade and (2) likely increased food price volatility as energy and food markets have become more closely connected as a result of increased biofuels production (De Gorter et al. 2013a, b; de Gorter and Drabik 2012; de Gorter and Just 2010; Serra and Zilberman 2013).

We contribute to the literature on energy prices, firstgeneration biofuels production and food prices by estimating the effects of biofuels production, oil prices and other factors, on an index of US food prices and an index of global food prices. Our contribution, with appropriate caveats, is to provide an empirically-based assessment of the contribution of biofuels production to recent food price spikes in terms of aggregate food price indexes rather than individual cereal prices. Thus, we offer potentially a more comprehensive understanding of the possible welfare impacts of biofuels production. We also combine, for the first time as far as we are aware, estimated models with projected oil prices and biofuels production out to 2040, sourced from the US Energy Information Administration, to quantify the possible effects on global food price of different scenarios of global biofuels production and oil prices in the decades to come. While our projections to 2040 are highly dependent on assumed energy prices and the growth in first-generation biofuels production, they do show that policies that support biofuels production, primarily in rich countries, would likely increase global food prices and, thus, generate a large and negative impact on the food security of the poor, primarily in low-income countries.

In the section "Effects of biofuel production and oil prices on food prices" we highlight some of the recent literature on biofuels production and oil prices on food prices, and outline the model we use to estimate the underlying relationships. Section "Data and Results" describes the data, the parameter estimates of the models we estimated for the US and global food prices, and the results. In Section "Discussion" we discuss the implications of our findings on food security and public policies towards biofuels subsidies and mandated levels of use in fuels. We offer concluding remarks in the "Conclusions" section.

\section{Effects of biofuel production and oil prices on food prices}

\section{Overview of biofuels production}

World production of first-generation biofuels is dominated by the production of ethanol which is used as a liquid fuel, primarily in transportation. In 2011, world production of ethanol was some 545 million barrels while world biodiesel production, another important output of biofuels production, was about 147 million barrels. The leading producers of ethanol and their global shares of world production in 2011 were the United States (61 \%) and Brazil (26\%). The major producers of biodiesel and their global output shares in 2011were the EU (44\%), the United States (16\%) and Brazil (11\%) (source: US Energy Information Administration's International Energy Statistics) (see Table 5 in Appendix).

In the US, the amount of corn crop devoted to ethanol production is large. For instance, in $20017 \%$ of US corn crop went to ethanol production, but this had increased to $20 \%$ in 2006, to about $40 \%$ in 2011 and was some $45 \%$ in 2013 . Similarly, in $2006-07,14 \%$ of US soybean oil was used in biodiesel production, but this share of soybean oil increased to about $30 \%$ in 2013. Despite this rapid and recent growth, there is very little additional growth foreseen in the US biofuels sector and the share of total corn use for ethanol may have already peaked in 2013 (source: USDA, Economics Research Service using data from Feed Grains).

In EU-25, bioethanol production is based mostly on wheat. In 2008, wheat-based ethanol accounted for $70 \%$ of total European bioethanol production with the remainder accounted for in descending order of importance by barley, corn and rye. By contrast, in Brazil, bioethanol production is completely based on sugarcane. The majority of the biodiesel production in the EU is based on rapeseed oil while in Brazil it is based on soybean oil.

The key point to understanding biofuels production is that it is supported by either subsidies or fuel mandates (Ziolkowska et al. 2010) in the main producing countries. Indeed, some countries have set mandates and goals to replace fossil fuels by biofuels. The current EU targets are that, by $2020,10 \%$ of energy used for transportation should be from biofuels. In the US, The 2007 Energy Independence and Security Act (EISAct 2007) specified a target of 9 billion 
gallons of renewable fuels in 2008 that increases to 36 billion gallons in 2022 (EISAct 2007). The Renewable Fuel Standard (RFS) was established by the Energy Policy Act of 2005 (EPAct 2005) and then expanded by the EISAct 2007. It requires the US Environmental Protection Agency (EPA) to set requirements for the renewable content of gasoline and diesel fuel. The EPA sets the RFS target volumes every year in reference to legislated targets in EISAct 2007, public comments, and input from other government agencies. Refiners and importers of gasoline and diesel fuel are obligated to blend renewable fuels in proportion to the volumes of gasoline and diesel fuel sold. In the absence of such fuel mandates or targets for biofuels use, especially ethanol, the price of biofuels would be substantially less and would only be priced relative to their energy content of fossil fuels (Chen and Khanna 2012; de Gorter et al. 2013b).

The US and worldwide biofuels production have increased rapidly in the past few years. This trend is not expected to continue for a number of reasons including the growth in US oil production from tight oil and shale formations and the related factor of lower current and expected oil prices. In the US, the EPA announced in its 2013 RFS final rule that it expected to reduce the total biofuel obligations to levels below the statutory levels for 2014. The total renewable fuels requirement is also assumed to grow slowly and to remain well below the legislated target of 36 billion gallons in 2022 (AEO 2014). As a result, the Energy Information Administration projects US biofuels production to increase at an annual rate of $0.5 \%$ and for global biofuel production to increase by $2.7 \%$ per year through to 2040 .

Estimated effects of biofuel production and oil prices on food prices

\section{Effects of biofuel production on food prices}

The main feedstocks currently used for biofuels production could be directly or indirectly used for food consumption, and are commonly called first-generation biofuel feedstocks. Second-generation biofuels come from feedstocks that are not directly part of the food supply (grain residues, wood, etc.) and are converted to biofuels using cellulosic conversion technologies. Second-generation biofuels currently only account for a very small amount of biofuels production (Janssen et al. 2013), but could become commercially competitive within 30 years (Hertel et al. 2013). Second-generation biofuel feedstocks may not directly reduce food availability, but if they use plant material that requires scarce land or inputs that could be used for food production then their production may also increase food prices. Third-generation biofuels feedstocks are currently being developed and trialled based on algae that would, in principle, not use arable land that would otherwise be used for food production.
There is already a large literature on the possible effects of biofuels production on food supply and food prices. This literature has recently been reviewed by Serra and Zilberman (2013) and Zilberman et al. (2012). We adapt the framework used by Zilberman et al. (2012) and classify these analyses into one of three groupings: (1) partial-elasticity analysis; (2) biofuels policies, or land-use change modelling or multimarket models and analyses; and (3) time-series analyses.

A series of partial-elasticity studies have investigated the effect of biofuels on food prices by using food demand and food supply elasticities to assess the price changes resulting from the change in food supply because of biofuel production. For instance, Roberts and Schlenker (2010) found that US biofuel mandates will increase the food price by $30 \%$, but this diminishes to $20 \%$ if a third of the biofuel calories are recycled as feedstock for livestock. Baier et al. (2009) estimated that the increase in worldwide biofuel production between June 2006 and June 2008 pushed up corn, soybean and sugar prices by 27,21 and $12 \%$, respectively. They observed that although biofuel production had a noticeable effect on individual crop prices, the effect of biofuels on the global food price was much smaller, and accounted for only about $12 \%$ of the rise in global food price between June 2006 and June 2008.

A key limitation of the partial-elasticity approach is that it does not allow other contributing factors that may cause foodprice inflation to be considered nor can it assess the relative importance of biofuels compared to other factors, such as the energy price. Mitchell (2008) found that higher energy prices and a weak US dollar accounted for $25-30 \%$ of the US food price increase between January 2002 and June 2008. The remaining $70-75 \%$ increase in food price was due to biofuels and the consequences of low grain stocks, land-use shifts, speculative trading and export bans.

A second grouping of the literature includes analyses that compare different biofuel policies, or use multimarket models, or examines effects from changes in land use. In terms of biofuel policies, de Gorter and Just (2010) show how an import tax on Brazilian ethanol increased US food prices. In terms of changes in land use, Chakravorty et al. (2009) conclude that, by the year 2020, with an increased price of fossil fuels, the diversion of land to produce first-generation biofuels may increase food prices between 65 and $75 \%$. In terms of multi-market models and analyses, Chakravorty et al. (2010) reported that biofuel mandates contributed to about one-third of the increase in food prices, while two-third of the increase came from increased food demand. Hochman et al. (2011) found that US biofuel contributed between 20 and $25 \%$ of the increase in the US corn price and contributed to $7-8 \%$ of the increase in soybean price between 2001 and 2007.

A third grouping of the literature is in terms of times-series analyses that is summarised by Serra and Zilberman (2013). They review 34 time-series analyses of biofuel-related effects 
on: (1) biofuel or energy prices; (2) fossil fuel prices in the long run; (3) the transmission to feedstock prices; and (4) volatility of prices. While results differ across studies, some key findings include: (1) fossil fuel prices are key drivers of long-run food prices; (2) biofuel prices have become increasingly important in linking energy and food markets; and (3) in the recent past, price volatility has been transmitted from fossil fuels to foods. Gilbert and Mugera (2014) have also found that increased biofuels production, in part, explains the increased volatility in food prices over the past decade.

\section{Effects of oil prices on food prices}

The relationship between fossil fuel prices and food prices is complex. First, higher oil prices raise the costs of agricultural production in terms of direct fuel use on farms and transportation as well as other inputs, such as fertilisers. Higher costs of food production, in turn, raise food prices. Second, as pointed out by Hertel and Beckman (2011), the relationship between oil prices and food prices depends on the nature of the relationship between biofuels and petroleum. If biofuels and petroleum are complements in fuels use, such as in the period 2001-2006, the growth in ethanol production was stimulated so as to replace the fuel additive MTBE as an oxygenator and not just as fuel in its own right, then higher oil prices does not necessarily result in increased prices of cereals used as biofuel feedstocks.

If biofuels and petroleum are used as substitutes, such as in the period 2007-2008, higher fossil fuel prices increase the profitability of biofuels production relative to food crop production. In turn, this encourages a positive supply response in terms of biofuel feedstocks which comes at the expense of food crop production due to substitution of factors of production, especially of land, away from food crops to biofuel feedstocks. This, in turn, reduces the food crop supply and contributes to higher food prices. After 2008, the US has moved into a period in which ethanol demand is alternately determined by the binding Renewable Fuel Standard and the currently limited capacity of refineries to ensure these standards are met, the so-called 'Blend Wall' that has helped to delink oil and biofuel prices (Hertel and Beckman 2011).

The empirical literature on the relationship between fuel prices and food prices is largely based on time-series regression analysis, with particular focus on the volatility between oil, biofuel and food prices (Serra 2013). One of the many studies include Alom et al. (2011) who used general autoregressive conditional heteroskedasticity models for Australia, New Zealand, and also selected Asian countries. In their modelling, they observed that oil prices positively influence food prices in mean and volatility with varying magnitudes among countries. Baffes (2007) also examined the effect of crude oil prices on the prices of internationally traded primary commodities. In their analysis, for the period
1960-2005, they found that the pass-through coefficient of crude oil price changes to agricultural commodity price was 0.17 .

Hao et al. (2013) observed a long-run cointegration relationship between biodiesel and soybean prices. Ciaian and Kancs (2011) also found a cointegration relationship with the crude oil price for typical biofuel crops as corn and soybean for the 1999-2003 period. Similarly, Hassouneh et al. (2012) observed a positive effect of energy prices on sunflower oil prices through short-run price dynamics. Positive effects of oil prices on food prices or on individual crop prices were also obtained by Abdel and Arshad (2009), Balcombe and Rapsomanikis (2008), Chaudhuri (2001), Kristoufek et al. (2012, 2013), Serra et al. (2011), and Bakhat and Wurzburg (2013). Contrary findings that report no statistically significant relationship between oil price and commodity food prices include Zhang et al. (2010), Yu et al. (2006), and Esmaeili and Shokoohi (2011). These contradictory results based on time-series results have, in turn, been criticised for failing to adequately account for the effects of biofuel policies (de Gorter et al. 2013b).

Model of oil prices and biofuels production on food prices

In our analysis of the effects of oil prices and biofuels production on food prices we estimate an equilibrium food price model whereby food prices are determined by current and past oil prices, biofuel production and per capita income. The estimated equilibrium price is derived from a demand and supply model where the demand for foods is defined by Eq. (1):

$D=\beta_{0}-\beta_{1} P+\beta_{2} B+\beta_{3} X$

where D: demand for foods; P: food price; B: Biofuel production that affects food demand; $\mathrm{X}$ : vector of other factors that affect food demand apart from food price and biofuel production; $\beta$ : are parameters with $\beta_{1}, \beta_{2}$ expected to be positive.

The supply of food is defined by Eq. (2):

$S=\gamma_{0}+\gamma_{1} P+\gamma_{2} Z$

where S: supply of foods; Z: vector of other factors that affect food supply apart from food price; $\gamma$ : are parameters with $\gamma_{1}$ expected to be positive.

The equilibrium food price is defined by equating the demand for foods and food supply as follows:

$D=S$

$\Rightarrow \beta_{0}-\beta_{1} P+\beta_{2} B+\beta_{3} X=\gamma_{0}+\gamma_{1} P+\gamma_{2} Z$

$\Rightarrow\left(\gamma_{1}+\beta_{1}\right) P=\left(\beta_{0}-\gamma_{0}\right)+\beta_{2} B+\beta_{3} X-\gamma_{2} Z$ 
The estimated equation is simplified to the following:

$P=\alpha_{0}+\alpha_{1} B+\alpha_{2} X+\alpha_{3} Z$

Equation (4) is estimated using United States data and global data to generate two sets of results.

\section{Data and results}

Data

The estimated model of US food prices uses annual data from the US over the period 1981-2013 that include: a US food price index with the base year 2013 (source: US Bureau of Labor Statistics), US biofuels production and US crude oil price (source: U.S. Energy Information Administration), and US real GDP per capita in 2005\$ (source: World Bank). For our out-of-sample forecast, we use the projected US crude oil price from 2014 to 2040 (source: EIA annual energy outlook 2014), and projected US GDP per capita in real 2005\$ for the period from 2014 to 2040 (source: US Department of Agriculture).

The estimated model of global food prices uses annual global data over the period 1980-2013 that include: a world food prices index with a base year 2010 and world nominal crude oil price (source: World Bank), data for global biofuel production obtained from the U.S. Energy Information Administration. For our out-of-sample forecast, we use the projected global crude oil price from 2014 to 2040 (source: EIA annual energy outlook 2014). The US crude oil price and US food prices index are graphed in Fig. 1 and the global crude oil price and global food price index are graphed in Fig. 2. The global prices presented in Fig. 2 clearly show that since 2006 food prices have closely followed crude oil prices.

\section{Results}

\section{US food prices index}

Our preliminary tests for the stationarity of the series used in the model suggest that all the series used are integrated of the same order, that is integrated of order one. The standard diagnostic test for stationarity of the error term of the model finds that the error term is stationary. The autoregressive coefficient of the model is 0.74 , which is statistically significantly and less than unity. The LM test and the Ljung-Box statistics indicate no evidence of autocorrelation in the error terms of the model which tests up to AR(12) in the Ljung-Box test and up to $\mathrm{AR}(4)$ in the LM test.

Collectively, the test results indicate that the relationship between the dependent variable (US food prices index) and independent variables is dynamically stable, the OLS

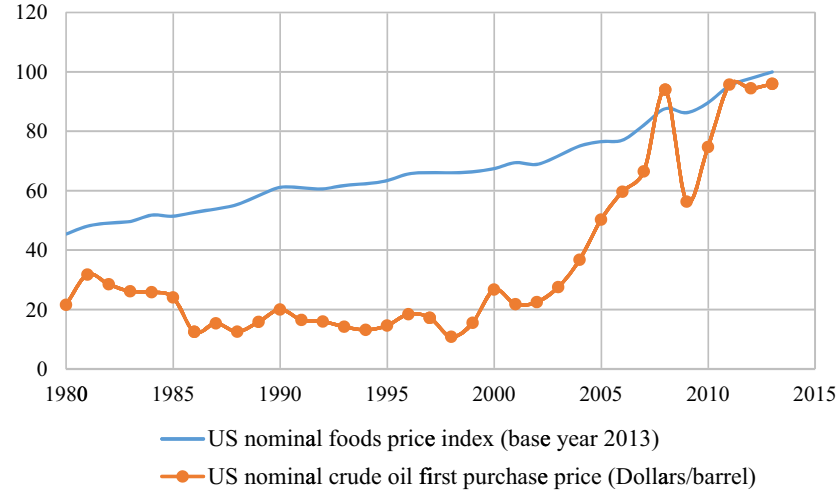

Fig. 1 US crude oil price and US food prices index

estimators are consistent and their asymptotic distributions converge to a normal distribution (Maekawa et al. 1996; Maddala and Kim 1998). Consequently, standard tests of significance of the estimated coefficients are appropriate.

For completeness, we used AIC and BIC criteria to choose between models where longer lags of explanatory variables were added into the model. We found that all the extra lagged variables were insignificant and AIC and BIC were both smallest in a model with a one-year lag, as reported in Table 1.

The estimated parameters provided in Table 1 show that the biofuels production coefficient is 0.02 and this coefficient is statistically significant at the $5 \%$ significance level. This implies that if US biofuel production were to increase by 10 million barrels per year, in the same year the US food prices would increase by $0.2 \%$ of the 2013 foods price. The estimated autoregressive coefficient is 0.74 which indicates that the long-run effect of an increase of 10 million barrels in biofuels production on food prices is to increase US foods price by $0.76 \%$ of the base year of 2013 US food prices.

The data show that US biofuel production increased by 44.7 million barrels between 2006 and 2007, and increased again by 70.9 million barrels between 2007 and 2008 while between 2007 and 2008 US foods price increased by $5.56 \%$ of the 2013 US foods price. Our results imply that out of this $5.56 \%$ increase in the US food prices, $2.1 \%$ was due to the increase in biofuel production between 2006 and 2008. In

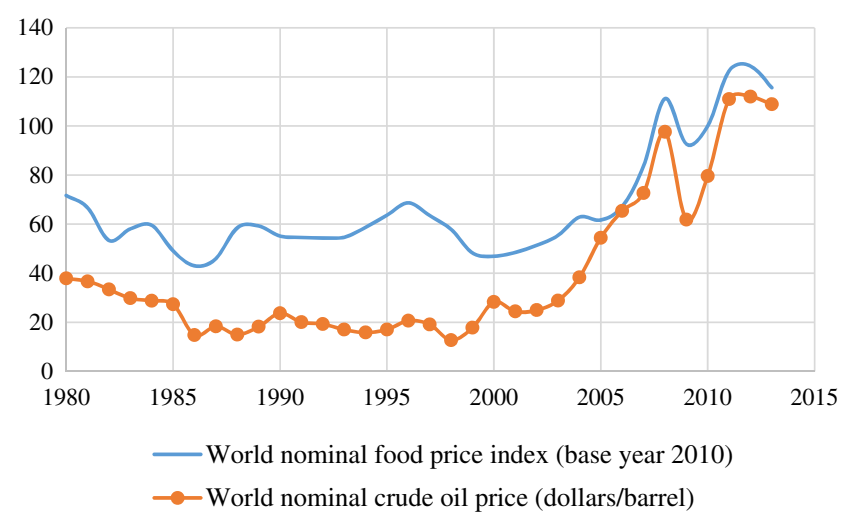

Fig. 2 Global crude oil price and global food prices index 
Table 1 Estimate Model of US foods price index

\begin{tabular}{|c|c|c|}
\hline \multirow[t]{2}{*}{ Variable } & \multicolumn{2}{|c|}{$\begin{array}{l}\text { US foods price index } \\
\text { (base year }=2013 \text { ) }\end{array}$} \\
\hline & Coefficient & $p$ Value \\
\hline Biofuels production (Million Barrel/year) & 0.020 & 0.032 \\
\hline Crude oil price (\$/Barrel) & 0.084 & 0.001 \\
\hline Crude oil price $(-1)(\$ /$ Barrel $)$ & -0.064 & 0.015 \\
\hline $\mathrm{Ln}(\mathrm{GDP}$ per capita) (in $2005 \$$ ) & 9.706 & 0.033 \\
\hline US foods price index $(-1)$ & 0.738 & 0.000 \\
\hline Intercept & -85.50 & 0.041 \\
\hline R_squared & \multicolumn{2}{|l|}{0.996} \\
\hline F_statistic & \multicolumn{2}{|c|}{$1203(p=0.000)$} \\
\hline LM test for $\mathrm{AR}(4)$ & \multicolumn{2}{|c|}{$\mathrm{F}=1.20(p=0.336)$} \\
\hline Ljung-Box test for AR(12) & \multicolumn{2}{|c|}{$\mathrm{Q}=8.12(p=0.776)$} \\
\hline ADF test statistic for stationarity of the residual & \multicolumn{2}{|c|}{$\begin{array}{l}\mathrm{t}_{\mathrm{obs}}=-6.36, \text { Critical } \\
\text { value at } 1 \%=-2.64\end{array}$} \\
\hline
\end{tabular}

other words, the model results imply that $38 \%$ of the increase in US food price index between 2007 and 2008 was due to the increase in US biofuel production between 2006 and 2008.

The estimated coefficient for the present period's crude oil price is 0.084 which is statistically significant at the $1 \%$ level. This implies that if US crude oil price were to increase by 10 dollars per barrel, in the same year, US foods price would increase by $0.84 \%$ of the 2013 foods price. The long-run effect of the oil price on foods price is to increase foods price by $0.76 \%$ of 2013 foods price for an increase of oil price by 10 dollars per barrel. The long-run effect of oil price is slightly smaller than the short-run effect.

US crude oil price increased by 6.83 dollars per barrel between 2006 and 2007, and increased by 27.5 dollars per barrel between 2007 and 2008. Our results indicate that given the increase in US food prices in 2008 was $5.56 \%$ of the 2013 US foods price, $2.30 \%$ was due to the increase in oil price between 2006 and 2008. In other words, according to our results, $41 \%$ of the increase in food prices between 2007 and 2008 was due to the increase in oil price between 2006 and 2008.

The coefficient of the natural logarithm of US real GDP per capita is 9.7 which is statistically significant at the $5 \%$ level of significance. This implies that the food price index would increase by about $1 \%$ of the 2013 food price for a $10 \%$ increase in real GDP per capita in the same year. The longrun effect of GDP per capita on US food prices is to increase food prices by $3.7 \%$ of the 2013 food price for an increase in real GDP per capita of $10 \%$.

Figure 3 presents the actual US food price index and the insample predicted US food price index from the model results in Table 1 and the predicted US food price index if there was no biofuels production in the US. The data shows that in the absence of biofuels production, US food prices index in 2013 would have been $7.2 \%$ lower.

\section{Contribution of biofuels and oil prices to 2040 food prices under different scenarios}

Future food prices are affected by the future relationship between food demand and food supply. Future food demand is strongly influenced by population and income growth. Future food supply is not only influenced by biofuels production, but is strongly affected by the rate of technological progress in the agricultural sector. Our study accounts for income growth and growth in population through the effect of GDP per capita, but we do not model the trends in agricultural productivity as has been done by Baldos and Hertel (2014), among others. As a result, the use of our model to forecast food price over a decade or longer periods is not recommended. As an alternative, we investigated the relative contribution of biofuels production and oil prices to 2040 US food prices under six different scenarios in terms of biofuels production and oil prices. Using projected US GDP per capita in real $2005 \$$ for the period from 2014 to 2040, sourced from the US Department of Agriculture, our analysis is on the deviations from a reference case in 2040 with different assumptions about biofuels production and oil prices.

Figure 4 represents deviations in US food price index under different scenarios of US biofuel production compared to the reference case. In the reference case, we assume that US biofuels production after 2014 remains at its 2013 level and we use projected US crude oil price to 2040, sourced from the EIA's annual energy outlook 2014, which grows at the rate of $2.7 \%$ per year on average.

The triangle-marked line and the dashed line represent the deviations in US food price index if US biofuels production were to grow at the compound rate of 2 and $0.5 \%$ per year from 2014, respectively. The circle-marked line represents the deviation in US food price index if US biofuels production

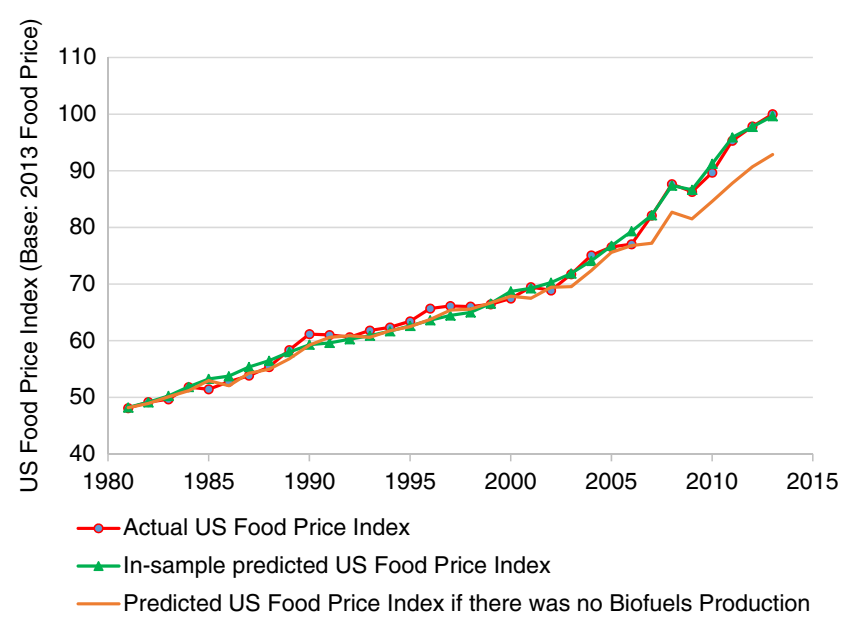

Fig. 3 Actual and predicted US food prices indexes 


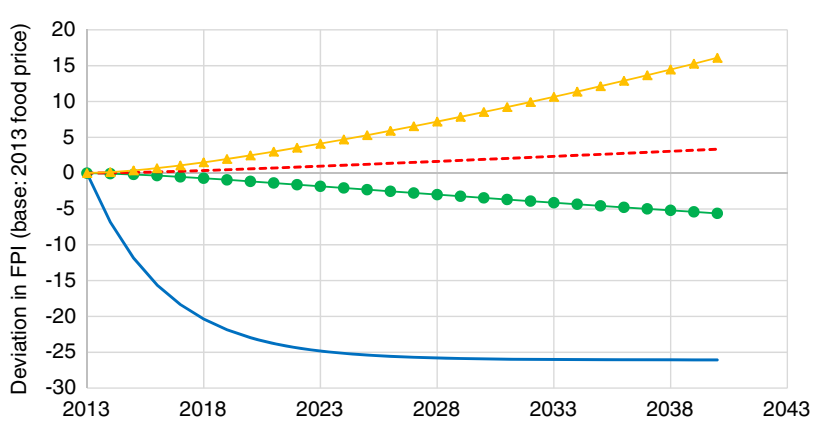

—Deviation in Food Price Index (FPI) if there were no Biofuels from 2014 $\longrightarrow$-Deviation in FPI if Biofuels production from 2014 decreases at 1 percent per year -.-.. Deviation in FPI if Biofuels production from 2014 grows at 0.5 percent per year _-Deviation in FPI if Biofuels production from 2014 grows at 2 percent per year

Fig. 4 Deviations in US Food Price Index: different scenarios of US biofuels production compared to reference case

was to decrease at the rate of $1 \%$ per year from 2014. The smooth, solid line is the deviation in US food price index for the period 2014-2040 if there were to be no biofuels from 2014.

The EIA predicted that US biofuels production will grow at an annual rate of $0.5 \%$ through 2040 . If this were to be the case, as shown by the dashed line in Fig. 4, the US food price index in 2040 would be about 3.5 percentage points higher than it would be if US biofuels production were to remain at its 2013 level. To see the potential contributions of different levels of biofuels production, we also consider the case where US biofuels production grows at the annual rate of $2 \%$ (which is 1.5 percentage points higher than predicted by the EIA), and the case US biofuels production decreases at the annual rate of $1 \%$ (which is 1.5 percentage points lower than predicted by the EIA) from 2014. Figure 4 shows that a growth in US firstgeneration biofuels production of $2 \%$ per year from 2014 would result in an increase in US food price in 2040 of $16 \%$ of the 2013 US food price compared to the reference case where US biofuels production remained at its 2013 level; and a reduction in US biofuels production of $1 \%$ per year from 2014 would reduce US food price in 2040 by $6 \%$ of the 2013 US food price compared to the reference case. Finally, if there were no biofuels from 2014, US food price index in 2040 would be about 26 percentage points lower than it would be if US biofuels production was to remain at 2013 level.

Figure 5 represents deviations in US food price index under different scenarios of oil prices compared to a reference case. In the reference case we assume that US oil price remains at its 2013 level and we assume US biofuels production from 2014 grows at the annual rate of $0.5 \%$, as predicted by the EIA.

The EIA provides the predicted US oil price for the period 2014-2040 in which the average annual growth rate over the period is $2.7 \%$. To see the potential contributions of different levels of oil prices, we consider scenarios where the US oil price grows at the annual rate of 2 and $4 \%$, and the case that US oil price decreases at the rate of $2 \%$ per year.

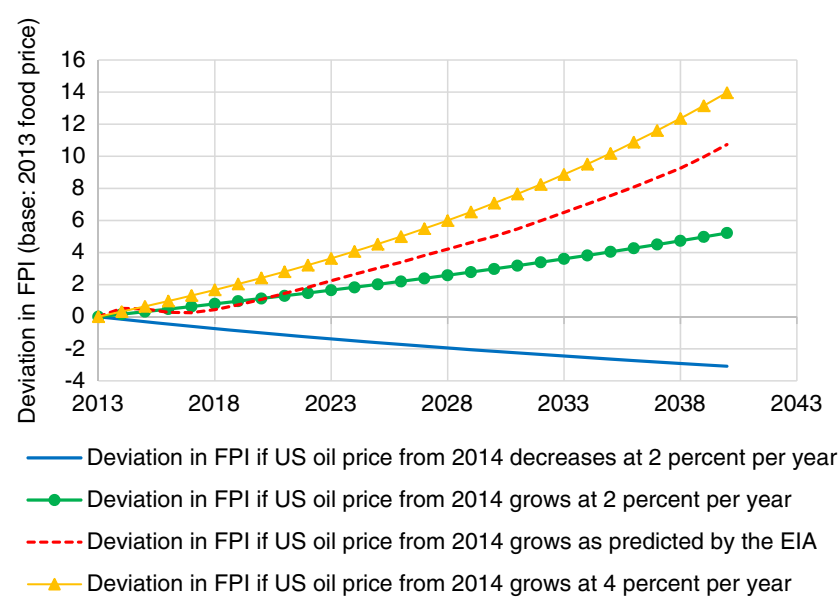

Fig. 5 Deviations in US Food Price Index: different scenarios of US oil prices compared to reference case

The deviation, compared to the reference case, in US food price if US oil price for the period 2014-2040, as predicted by the EIA, is represented by the dashed line. The trianglemarked line and the circle-marked line represent the deviations in US food price index if US oil price were to grow at the compound rate of $4 \%$ and $2 \%$ per year from 2014 , respectively. The smooth, solid line is the deviation in US food price index for the period 2014-2040 if the US oil price were to decrease at the annual rate of $2 \%$ from 2014.

As shown in Fig. 5, a growth in the US oil price of $4 \%$ (or $2 \%$ ) per year from 2014 would result in an increase in US food price in 2040 of about $14 \%$ (or $5.2 \%$ ) of the 2013 US food price compared to the reference case where US oil price remained at its 2013 level. A reduction in US oil price of $2 \%$ per year from 2014 would reduce US food price in 2040 by $3.1 \%$ of the 2013 US food price compared to the reference case. If US oil price's movement for the period 2014-2040 were to occur as predicted by the EIA, with average annual growth rate of $2.7 \%$, US food price in 2040 would increase by about $11 \%$ of the 2013 US food price compared to the case where the US oil price from 2014 to 2040 were to remain at its 2013 level.

\section{Global food price index}

Table 2 reports the model results using a global food prices index and global biofuels production. The estimated coefficient on biofuel production is 0.027 and it is statistically significant at the $10 \%$ level. This implies that the short-run effect of an increase in global biofuel production by 100 million barrels per year is to increase the global food prices by $2.7 \%$ of the 2010 global foods price. The autoregressive coefficient is 0.57 which implies that the long-run effect of global biofuels production on global food prices is to increase the global food price by $6.25 \%$ of the 2010 global foods price for 
Table 2 Estimate model of global foods price index

\begin{tabular}{llc}
\hline Variable & \multicolumn{2}{l}{$\begin{array}{l}\text { Global foods price index } \\
\text { (base year }=2010)\end{array}$} \\
\cline { 2 - 3 } & Coefficient & $p$ Value \\
\hline Biofuels production (Million Barrel/year) & 0.027 & 0.090 \\
Crude oil price (\$/Barrel) & 0.459 & 0.001 \\
Crude oil price (-1) (\$/Barrel) & -0.331 & 0.025 \\
Global foods price index (-1) & 0.568 & 0.003 \\
Intercept & 17.75 & 0.007 \\
R_squared & 0.94 & \\
F_statistic & $109.6(p=0.000)$ \\
LM test for AR(4) & $\mathrm{F}=0.906(p=0.476)$ \\
Ljung-Box test for AR(12) & $\mathrm{Q}=9.32(p=0.675)$ \\
ADF test statistic for stationarity of the residual & $\mathrm{t}_{\text {obs }}=-4.65$, Critical \\
& \multicolumn{2}{c}{ value at $1 \%=-2.64$} \\
\hline
\end{tabular}

an increase of 100 million barrels per year of global biofuel production

Between 2006 and 2007, global biofuel production increased by 96 million barrels, and increased again by 136.5 million barrels between 2007 and 2008. Between 2007 and 2008 the increase in the global food price index represented $27.5 \%$ of the 2010 global food prices. Our results imply that $5.2 \%$ of the $27.5 \%$ increase was due to higher global biofuel production between 2006 and 2008. In other words, about $19 \%$ of the increase in global food prices in 2008 was due to the increase in global biofuel production between 2006 and 2008.

The estimated coefficient for the crude oil price is 0.459 , as shown in Table 2, and is statistically significant at the $1 \%$ level of significance. This implies that if the global crude oil price were to increase by 10 dollars per barrel, in the same year, the global food price index would increase by $4.6 \%$ of the 2010 global food prices. The long-run effect of the oil price on food price is to increase the global food price index by $2.96 \%$ of 2010 food price for an increase of global oil price by 10 dollars per barrel.

Between 2006 and 2007, the global crude oil price increased by 7.3 dollars per barrel and increased by 24.9 dollars per barrel between 2007 and 2008. Our results indicate that increases in oil prices between 2006 and 2008 contributed to $10.9 \%$ of the $27.5 \%$ increase in the global food price index that occurred in 2008. In other words, according to the results in Table 2 , about $40 \%$ of the increase in the global food prices index in 2008 was due to the increase in oil price between 2006 and 2008 .

Figure 6 presents the actual global food price index, the insample predicted global food price index and the predicted global food price index if there was no global biofuels production. Our results show that with no biofuels production, the

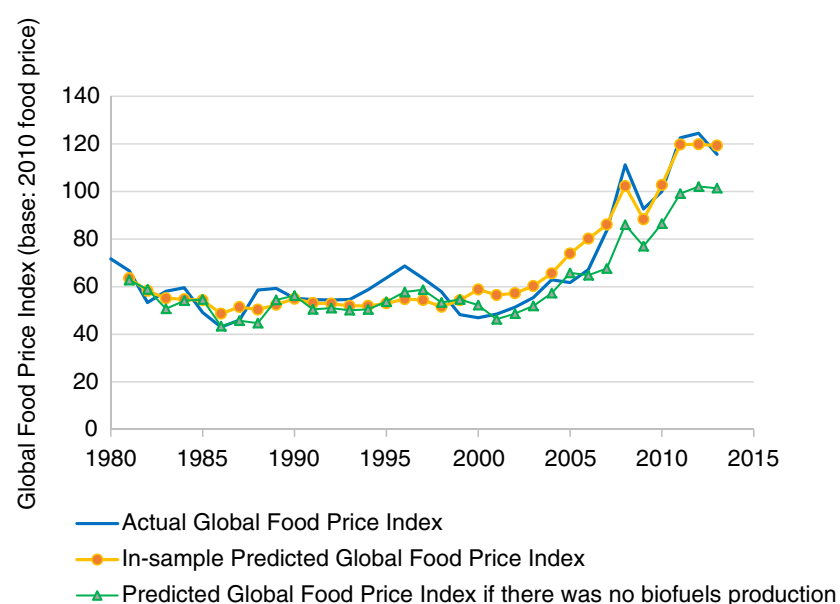

Fig. 6 Actual and predicted global food price indexes

global food prices index in 2008 would have been about $23 \%$ lower, that is, the index would have been 86 instead of its actual value 111. Our finding is that biofuels production increased the global food price index in 2010 by $14 \%$, and increased the global food price in 2013 by $12 \%$.

The EIA's annual energy outlook 2014 predicts that global production of biofuels grows at the compound rate of $2.7 \%$ per annum through to 2040 . The EIA also provides the projection for the global crude oil price for the period 2014-2040 in which the average annual growth rate is $2.7 \%$. We vary these assumptions and focus on the deviations from a reference case which arise from different assumptions about global biofuels production and global oil price.

Figure 7 represents deviations in the global food price index under different scenarios of global biofuel production compared to reference case. In the reference case we assume that global biofuels production after 2014 remains at its 2013 level and we use projected global crude oil price to 2040 sourced from the EIA annual energy outlook 2014 which grows at the annual rate of $2.7 \%$, on average. The first scenario assumes that the global production of biofuels grows at the compound rate of $2.7 \%$ per annum through to 2040 as predicted by the EIA. We consider a second scenario where we suppose that global biofuels production from 2014 grows at the annual rate of $1.5 \%$, and also a third scenario where global biofuels production decreases at the annual rate of $1 \%$. We also include a fourth scenario where there is no global biofuels production.

The triangle-marked line and the dashed line represent the deviations in global food price index if global biofuels production were to grow at the compound rate of 2.7 and $1.5 \%$ per year from 2014, respectively. The circle-marked line represents the deviation in global food price index if global biofuels production were to decrease at the annual rate of $1 \%$ from 2014. The smooth, solid line is the deviation in global food price index for the period 2014-2040 if there was to be no global biofuels production from 2014. 
Fig. 7 Deviations in Global Food Price Index: different scenarios of global biofuels production compared to reference case

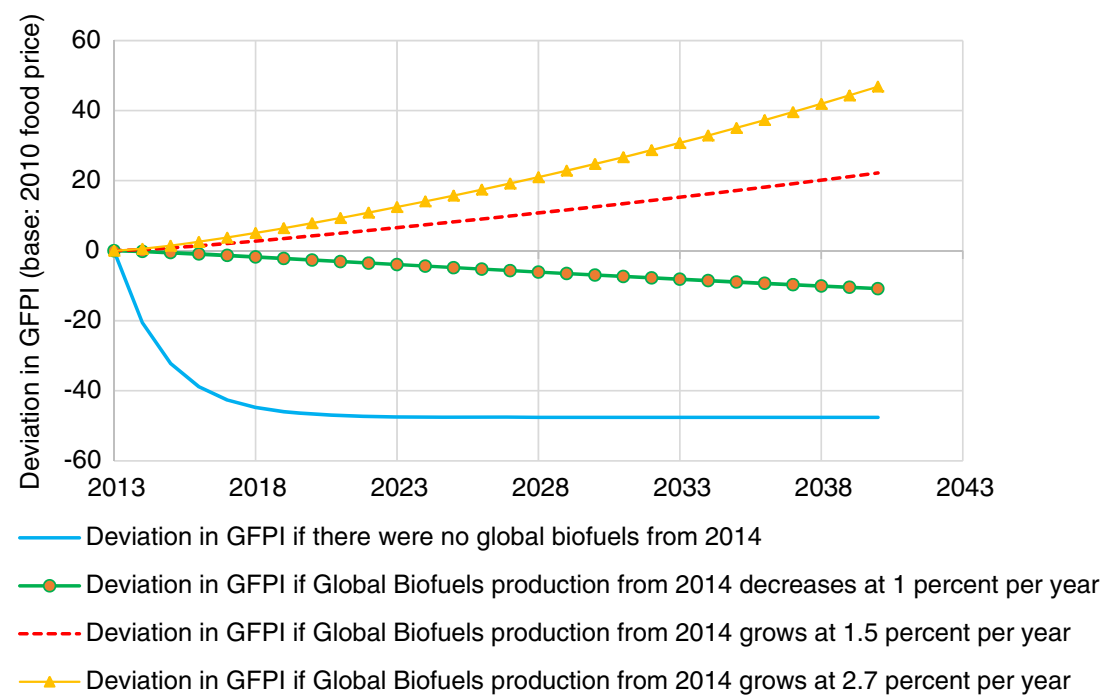

As shown by Fig. 7, a growth in global first-generation biofuels production of $2.7 \%$ (or $1.5 \%$ ) per year from 2014 would result in an increase in global food price in 2040 of $47 \%$ (or $22 \%$ ) of the 2010 global food price compared to the reference case where global biofuels production remained at its 2013 level. A reduction in global biofuels production of $1 \%$ per year from 2014 would reduce the global food price in 2040 by $11 \%$ of the 2010 global food price compared to the reference case. Finally, if there were no global biofuels from 2014, the global food price index in 2040 would be about 48 percentage points lower than it would be if global biofuels production were to remain at its 2013 level.

Figure 8 represents deviations in global food price index under different scenarios of global oil prices compared to the reference case where in the reference case we assume that global oil price after 2014 remains at the 2013 level, and global biofuels production grows at the annual rate of $2.7 \%$ as predicted by the EIA. In the first scenario we use EIA's projected global oil price for period 2014-2040 with an

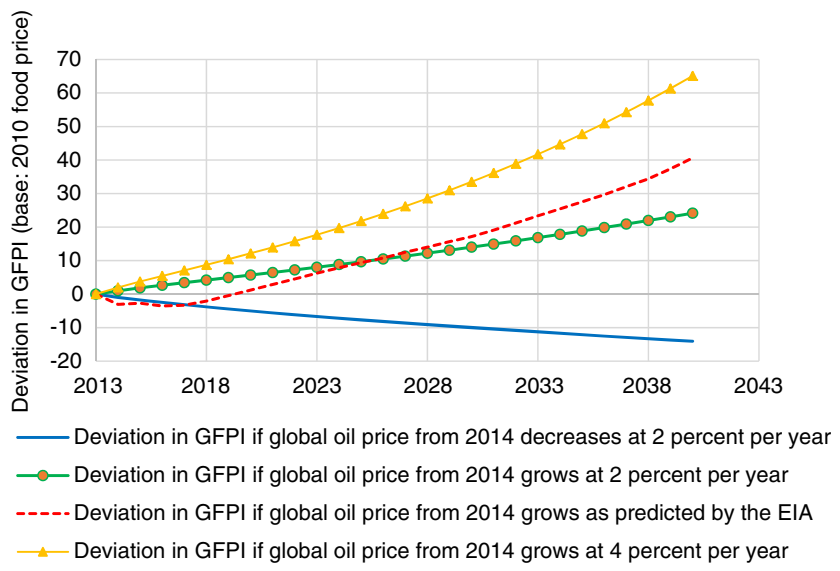

Fig. 8 Deviations in Global Food Price Index: different scenarios of global oil prices compared to reference case average annual growth rate of $2.7 \%$ over the period. In other scenarios we consider the cases where global oil price grows at the annual rate of 2 and $4 \%$. We also consider the case of global oil price decreasing at the annual rate of $2 \%$.

The deviation in global food price between the reference case that global oil price remains at its 2013 level and if the global oil price for the period 2014-2040 is as predicted by the EIA, is represented by the dashed line. The global oil price is predicted to decrease between 2014 and 2020 and, as a result, the deviation is negative in the 2014-2020 period such that the global food price index declines relative to the reference case. According to the EIA, the global oil price is predicted to increase steadily after 2020 with an average annual growth rate of $2.7 \%$ over the whole period. This growth in global oil price results in an increase in the global food price in 2040 of $41 \%$ of the 2010 global food price, compared to the reference case. A growth in the global oil price of $4 \%$ (or $2 \%$ ) per year from 2014 would increase the global food price in 2040 by $65 \%$ (or $24 \%$ ) of the 2010 global food price. A reduction in global oil price of $2 \%$ per year from 2014 would reduce global food price in 2040 by $14 \%$ of the 2010 global food price, compared to the reference case.

\section{Discussion}

Our model results indicate that biofuels production and oil prices are both important drivers of food-price inflation. The main findings are summarised in Table 3 . In the US, biofuels production between 2006 and 2008 accounted for $38 \%$ of the increase in US food price between 2007 and 2008 while $41 \%$ of the increase in US food price index between 2007 and 2008 was due to the rise in the crude oil price between 2006 and 2008. At a global level, about $19 \%$ of the increase in global food price index between 2007 and 2008 was caused by the 
Table 3 Effects of US and global crude oil price and US and global biofuels production on US and global food prices

\begin{tabular}{|c|c|c|}
\hline & Effects on US food price index with base year 2013 & \\
\hline & $\begin{array}{l}\text { Of an increase of } 10 \text { million barrels a year in US biofuel } \\
\text { production }\end{array}$ & Of an increase of 10 dollars per barrel in US crude oil price \\
\hline Short-run effect & Increase 0.2 percentage points & Increase 0.84 percentage points \\
\hline \multirow[t]{5}{*}{ Long-run effect } & Increase 0.76 percentage points & Increase 0.76 percentage points \\
\hline & Effects on US food price spike in 2007-08 & \\
\hline & $\begin{array}{l}38 \% \text { was due to increase in US biofuel production } \\
\text { between } 2006 \text { and } 2008\end{array}$ & $\begin{array}{l}41 \% \text { was due to the increase in US crude oil price between } \\
2006 \text { and } 2008\end{array}$ \\
\hline & Effect on global food price index with base year 2010 & \\
\hline & $\begin{array}{l}\text { Of an increase of } 100 \text { million barrels a year in global } \\
\text { biofuel production }\end{array}$ & Of an increase of 10 dollars per barrel in global oil price \\
\hline Short-run effect & Increase 2.7 percentage points & Increase 4.6 percentage points \\
\hline \multirow[t]{3}{*}{ Long-run effect } & Increase 6.26 percentage points & Increase 2.96 percentage points \\
\hline & Effects on global food price spike in 2007-08 & \\
\hline & $\begin{array}{l}19 \% \text { was due to increase in global biofuel production } \\
\text { between } 2006 \text { and } 2008\end{array}$ & $\begin{array}{l}40 \% \text { was due to the increase in global crude oil price between } \\
2006 \text { and } 2008\end{array}$ \\
\hline
\end{tabular}

increase in global biofuel production between 2006 and 2008 while the increase in crude oil price between 2006 and 2008 accounted for about $40 \%$ of the increase in global food price index in 2008.

Our findings indicate that in 2013 the US food price would have been $7.2 \%$ lower and the global food price would have been $12 \%$ lower if there had been no biofuels production. If there had been no biofuels production, the global food price during the 2008 price spike would have been about $23 \%$ lower.

Our analysis of the potential contributions of different levels of biofuels production (Table 4) indicates that a growth of $0.5 \%$ per year from 2014 in US biofuels production (as predicted by the EIA) would increase the US food price in 2040 by $3.5 \%$ of the 2013 US food price, compared to the reference case where US biofuels production remains at its 2013 level. If US first-generation biofuels production from 2014 grows at the annual rate of $2 \%$, US food price in 2040 would increase by $16 \%$ of the 2013 US food price. If US biofuels production decreases at the annual rate of $1 \%$, the US food price in 2040 would be lower by $6 \%$ of the 2013 US food price compared to the reference case. If there were no biofuels from 2014 , US food price would be lower by $26 \%$ of the 2013 US food price compared to the reference case where US biofuels production was to remain at 2013 level.

At a global level, compared to the reference case where global biofuels production remained at its 2013 level, a growth in global biofuels production of $2.7 \%$ per year, as predicted by the EIA (or a growth of $1.5 \%$ per year) from 2014 , would increase global food price in 2040 by $47 \%$ (or $22 \%$ ) of the 2010 global food price. A reduction in global biofuels production at the rate of $1 \%$ per year from 2014 would reduce the global food price in 2040 by $11 \%$ of the 2010 global food price. If there were no global biofuels from
2014 , the global food price in 2040 would be lower by $48 \%$ of the 2010 global food price, compared to the reference case.

Oil prices had strong effects on food price for both the US and at global level (see Table 4). Compared to the reference case where the US oil price remains at its 2013 level, if the US oil price from 2014 grows as predicted by the EIA with an average annual growth rate of $2.7 \%$ over the whole period 2014-2040, the US food price would increase by about $11 \%$ of the 2013 US food price. If the US oil price from 2014 grows at the rate of $4 \%$ (or $2 \%$ ) per year, US food price in 2040 would be higher than in the reference case by $14 \%$ (or $5.2 \%$ ) of the 2013 US food price. If US oil price decreases at the annual rate of $2 \%$ from 2014, US food price index in 2040 would be $3.1 \%$ age points lower compared to the reference case.

At a global level, if the global oil price for the period 2014 2040 is as predicted by the EIA then the global food price in 2040 would increase by 41 percent of the 2010 global food price, compared to the reference case where global oil price remains at its 2013 level. If the global oil price grows at the rate of $4 \%$ (or $2 \%$ ) per year from 2014, the global food price in 2040 would increase by $65 \%$ (or $24 \%$ ) of the 2010 global food price. A reduction of $2 \%$ per year in the global oil price would reduce global food price in 2040 by $14 \%$ of the 2010 global food price, compared to the reference case.

The key implication of our findings for global food security is that both higher oil prices and increased biofuels production raise food prices. High food prices are expected to have a strongly negative effect on livestock producers who face higher feed and energy costs, and also on the urban poor and the major food importing developing countries because a higher share of their income will be required to purchase food. According to the OECD, each $10 \%$ increase in prices of all cereals add about USD 4.5 billion to the cereals import bill of 
Table 4 Effects on food price of different scenarios of biofuels production and oil prices

\begin{tabular}{|c|c|c|}
\hline & \multicolumn{2}{|c|}{ Effects on US food price index in 2040: base year 2013} \\
\hline & & $\begin{array}{l}\text { Compared to reference case where US biofuels } \\
\text { production remains at its } 2013 \text { level }\end{array}$ \\
\hline \multirow{5}{*}{$\begin{array}{l}\text { If annual growth rate of US biofuels production } \\
\text { from } 2014 \text { is }\end{array}$} & $0.5 \%$ & Increase 3.5 percentage points \\
\hline & $2 \%$ & Increase 16 percentage points \\
\hline & decrease at rate $1 \%$ & Decrease 6 percentage points \\
\hline & No biofuels from 2014 & Decrease 26 percentage points \\
\hline & & $\begin{array}{l}\text { Compared to reference case where US oil price } \\
\text { remains at its } 2013 \text { level }\end{array}$ \\
\hline \multirow[t]{6}{*}{ If annual growth rate of US oil price from 2014 is } & average $2.7 \%$ (as predicted by the EIA) & Increase 11 percentage points \\
\hline & $4 \%$ & Increase 14 percentage points \\
\hline & $2 \%$ & Increase $5.2 \%$ age points \\
\hline & decrease at rate 2 percent & decrease 3.1 percentage points \\
\hline & Effects on global food price index in 204 & : base year 2010 \\
\hline & & $\begin{array}{l}\text { Compared to reference case where global biofuels } \\
\text { production remains at its } 2010 \text { level }\end{array}$ \\
\hline \multirow{5}{*}{$\begin{array}{l}\text { If annual growth rate of global biofuels production } \\
\text { from } 2014 \text { is }\end{array}$} & $2.7 \%$ (as predicted by the EIA) & Increase 47 percentage points \\
\hline & $1.5 \%$ & Increase 22 percentage points \\
\hline & decrease at rate $1 \%$ & Decrease 11 percentage points \\
\hline & No biofuels from 2014 & Decrease 48 percentage points \\
\hline & & $\begin{array}{l}\text { Compared to reference case where global oil price } \\
\text { remains at its } 2010 \text { level }\end{array}$ \\
\hline \multirow[t]{4}{*}{ If annual growth rate of global oil price from 2014 is } & average $2.7 \%$ (as predicted by the EIA) & Increase 41 percentage points \\
\hline & $4 \%$ & Increase 65 percentage points \\
\hline & $2 \%$ & Increase 24 percentage points \\
\hline & decrease at rate $2 \%$ & decrease 14 percentage points \\
\hline
\end{tabular}

cereal-net importing countries (OECD 2008). Given that the poorest households in low-income countries spend more than half of their income on food, any large food price increases can be catastrophic as it is the equivalent to a substantial fall in disposable income.

While households can, and do, substitute to lower-priced foods and also reallocate their household spending, large increases in the price of major staples contributes greatly to increased hunger and undernourishment of poor households that are net consumer of food. Indeed, the World Bank (Global Monitoring Report 2012) observes that the 2007-2008 food price spike kept or placed 105 million people at below the poverty line and, as a consequence of the 2010-2011 food price spike, 44 million people fell below the extreme poverty line.

In terms of hunger and nutrition, the United Nations Food and Agriculture Organization (FAO) reports that over the last 20 years world food production has risen steadily at the rate of $2 \%$ per year, while the global population growth rate was $1.14 \%$ per year. Despite the overall favourable trend, the FAO estimates that over the period 2007-2009, 867 million people in the world were undernourished, and this number increased to 868 million over the period 2010-2012 (FAO 2012).
The implications of our results are several. First, subsidies and minimum fuel mandates for first-generation biofuels have contributed to food insecurity of poor net consumers of food in low-income countries. Second, if oil prices were to remain at a high level, which would promote biofuels production, priority should be given to mitigate the effects on food security of the poor. Third, if public assistance is provided to promote first-generation biofuels production for the purpose of reducing greenhouse gas emissions, the costs that such policies impose on food security on the undernourished and vulnerable must be explicitly considered in any policy evaluations of their costs and benefits.

\section{Conclusions}

Using US data for the period 1981-2013 and global data for the period 1980-2013, we estimate the effects of biofuels production and the crude oil price on US and global food price indexes. Our results indicate that both biofuel production and crude oil price have a statistically significant and economically significant effect on increased food prices. In particular, we find that if US biofuels production were to increase by 10 million barrel per year, the US food price index would 
increase by 0.2 percentage points in the short-run, and by 0.76 percentage points in the long run. The short-run effect of an increase of 10 dollars per barrel per year in the US oil price would be to increase the US food price index by 0.84 percentage points while the long-run effect would be to increase US food prices by 0.76 percentage points.

At a global level, if global biofuels production were to increase by 100 million barrels per year, the global food price would increase by 2.7 percentage points in the short run, and increase by 6.3 percentage points in the long run. The shortrun effect of an increase of 10 dollars per barrel per year in the global oil price would be to increase the global food price index by 4.6 percentage points while the long-run effect would be to increase the global food price by 3.0 percentage points.

Our findings suggest that about $38 \%$ of the increase in US food price index between 2007 and 2008 was caused by the increase in US biofuels production between 2006 and 2008, and about $41 \%$ was the result of an increase in the US oil price between 2006 and 2008. Globally, about $19 \%$ of the increase in the global food prices index in 2008 was caused by the increase in global biofuel production between 2006 and 2008 , and about $40 \%$ was due to the increase in the global oil price between 2006 and 2008 .

Using our model results and with projected oil prices and biofuels production to 2040 sourced from the US Energy Information Administration, we generate a reference case in terms of the effect on global food prices. Relative to a reference case where global biofuels production remains at its 2013 level then an annual growth in global biofuels production of $2.7 \%$, as predicted by the EIA, would increase global food price index in 2040 by 47 percentage points. If the global oil price for the period 2014-2040 grows as predicted by the EIA, the global food price in 2040 would increase by 41 percentage point compared to the reference case where the global oil price remains at its 2013 level. Notwithstanding caveats about the challenge of constructing a meaningful single index of global food prices, measurement and possible multicollinearity issues of independent variables, long-term supply responses for food supply and shift to second-generation biofuels production at the expense of first-generation biofuels, both our empirical results and food price deviations from a reference case to 2040 are important.

First and foremost, we show that subsidies and fuel mandates of first-generation biofuels have already contributed to food insecurity and will likely do so in the future. Second, if high oil prices continue they would represent a clear and present danger to people currently undernourished or vulnerable to being undernourished. Overall, our findings indicate that feeding more than 9 billion by 2050, and responding to current and future food security challenges, requires much more than an increase in crop yields per hectare. It demands a comprehensive set of policies that account for the inter- linkages across food, energy, water and the environment, and policy approaches that support the livelihoods of the poor and vulnerable.

Acknowledgments This paper was part of a workshop sponsored by the OECD Co-operative Research Programme on Biological Resource Management for Sustainable Agricultural Systems.

\section{Appendix}

Table 5 Data sources

\begin{tabular}{|c|c|}
\hline Variable & Data source \\
\hline US food price index, 1981-2013 & US Bureau of Labor Statisti \\
\hline US biofuels production, 1981-2013 & $\begin{array}{l}\text { U.S. Energy Information } \\
\text { Administration }\end{array}$ \\
\hline $\begin{array}{l}\text { US nominal crude oil price, } \\
\text { 1981-2013 }\end{array}$ & $\begin{array}{l}\text { U.S. Energy Information } \\
\text { Administration }\end{array}$ \\
\hline $\begin{array}{l}\text { US real GDP per capita in } 2005 \$ \text {, } \\
1981-2013\end{array}$ & World Bank \\
\hline $\begin{array}{l}\text { Projected US crude oil price, } \\
\quad 2014-2040\end{array}$ & $\begin{array}{l}\text { EIA annual energy outlook } \\
2014\end{array}$ \\
\hline $\begin{array}{l}\text { Projected US GDP per capita in } \\
\text { real } 2005 \$\end{array}$ & US Department of agriculture \\
\hline World food price index, 1980-2013 & World Bank \\
\hline $\begin{array}{l}\text { World nominal crude oil price, } \\
\text { 1980-2013 }\end{array}$ & World Bank \\
\hline $\begin{array}{l}\text { World real GDP per capita in } 2005 \$ \text {, } \\
1980-2013\end{array}$ & World Bank \\
\hline Global biofuel production, $1980-2013$ & $\begin{array}{l}\text { U.S. Energy Information } \\
\text { Administration }\end{array}$ \\
\hline $\begin{array}{l}\text { Projected global crude oil price, } \\
\quad 2014-2040\end{array}$ & $\begin{array}{l}\text { EIA annual energy outlook } \\
2014\end{array}$ \\
\hline
\end{tabular}

\section{References}

Abbott, P.C., Hunt C., Tyner, W.E. (2011). What's driving food prices in 2011? Farm Foundation issue report.

Abdel, H. A., \& Arshad, F. M. (2009). The impact of petroleum prices on vegetable oils prices: evidence from cointegration tests. Oil Palm Industry Economic Journal, 9, 31-40. Paper presented at the International Borneo Business Conference on Global Changes, Malaysia, December 2008.

AEO. (2014). Annual Energy Outlook with projections to 2040. US Energy Information Administration. www.eia.gov/forecasts/aeo/ pdf $/ 0383 \% 282014 \% 29$.pdf

Alom, F., Ward, B., Baiding, H. (2011). Spillover effects of world prices on food prices: Evidence from Asia and Pacific countries. 52nd New Zealand Association of Economists Annual Conference, Wellington, New Zealand, 29 June - 1 July 2011.

Baffes, J. (2007). Oil spills on other commodities. Resource Policy, 32, $126-134$ 
Baier, S., Clements, M., Griffiths, C., Ihrig, J. (2009). Biofuels impact on crop and food prices: Using an interactive spreadsheet. Board of Governors of the Federal Reserve System. International Finance Discussion Papers, No. 967. www.federalreserve.gov/pubs/ifdp/ 2009/967/ifdp967.pdf

Bakhat, M. \& Wurzburg, K. (2013). Price relationships of crude oil and food commodities. Economics for energy. Working Paper FA06/2013, viewed online 24 July 2014, http://www. eforenergy.org/docpublicaciones/documentos-de-trabajo/WPFA062013.pdf

Balcombe, K., \& Rapsomanikis, G. (2008). Bayesian estimation and selection of nonlinear vector error correction models: the case of the sugar-ethanol-oil nexus in Brazil. American Journal of Agricultural Economics, 90(3), 658-668.

Baldos, U. L. C., \& Hertel, T. W. (2014). Global food security in 2050: the role of agricultural productivity and climate change. Australian Journal of Agricultural and Resource Economics, 58, $1-18$.

Chakravorty, U., Hubert, M. H., \& Nostbakken, L. (2009). Fuel versus food. Annual Review of Resource Economics, 1, 645-663.

Chakravorty, U., Hubert, M.H., Moreaux, M., Nostbakken, L. (2010). Will biofuel mandates raise food prices? Working Paper No. 2011-01, University of Alberta.

Chaudhuri, K. (2001). Long-run prices of primary commodities and oil prices. Applied Economics, 33, 531-538.

Chen, X., \& Khanna, M. (2012). Food vs. fuel: the effect of biofuel policies. American Journal of Agricultural Economics, 95(2), 289-295.

Ciaian, P. \& Kancs, d'A. (2011). Interdependencies in the energybioenergy-food price systems: A cointegration analysis. Resource and Energy Economics. 33: 326-348.

de Gorter, H., \& Drabik, D. (2012). Policy update: the effect of biofuel policies on food grain commodity prices. Biofuels, $3(1), 21-24$.

de Gorter, H., \& Just, D. R. (2010). The social costs and benefits of biofuels: the intersection of environmental: energy and agricultural policy. Applied Economic Perspectives and Policy, 32(1), 4-32.

de Gorter, H., Drabik, D., \& Just, D. R. (2013a). Biofuel policies and food grain commodity prices 2006-20012: all boom and no bust? AgBioforum, 16(1), 1-13.

de Gorter, H., Drabik, D., Just, D. R., \& Kliauga, E. M. (2013b). The impact of OECD biofuels policies on developing countries. Agricultural Economics, 44, 477-486.

EISAct (2007). The US Energy Independence and Security Act of 2007. Public Law 110-140, 121 Stat. 1492, HR6, United States. www. gpo.gov/fdsys/pkg/BILLS-110hr6enr/pdf/BILLS-110hr6enr.pdf

Elobeid, A. M., \& Tokgöz, S. (2007). The 'new link' between energy and agriculture. Farm Policy Journal, 4(2), 12-27.

EPAct (2005). The Energy Policy Act of 2005. Public Law 109-58, 119 Stat. 594, HR6, United States. www.gpo.gov/fdsys/pkg/PLAW109pub158/pdf/PLAW-109pub158.pdf

Esmaeili, A., \& Shokoohi, Z. (2011). Assessing the effect of oil price on world food prices: application of principal component analysis. Energy Policy, 39, 1022-1025.

Food and Agriculture Organization (FAO). (2012). The State of Food Insecurity in the World 2012. http://www.fao.org/docrep/016/ i3027e/i3027e00.htm

Gilbert, C. L., \& Mugera, H. K. (2014). Food commodity prices volatility: the role of biofuels. Natural Resources, 5, 200-212.

Global Monitoring Report. (2012). Food prices, nutrition, and the millennium development goals, World Bank.

Hao, N., Colson. G., Karali, B., Wetzstein, M. (2013). Food before Biodiesel Fuel? Selected Paper prepared for presentation at the Southern Agricultural Economics Association (SAEA) Annual Meeting, Orlando, Florida, 3-5 February 2013.
Hassouneh, I., Serra, T., Goodwin, B. K., \& Jil, J. M. (2012). Nonparametric and parametric modeling of biodiesel, sunflower oil, and crude oil price relationships. Energy Economics, 34, 15071513.

Hertel, TW. \& Beckman, J. (2011). Commodity price volatility in the biofuel era: An examination of the linkage between energy and agricultural markets. The National Bureau of Economics Research, NBER Working Paper No. 16824. www.nber.org/ papers/w16824

Hertel, T., Steinbuks, J., \& Baldos, U. (2013). Competition for land in the global bioeconomy. Agricultural Economics, 44(1), 129-138.

Hochman, G., Rajagopal, D., Timilsina G., Zilberman, D. (2011). The role of inventory adjustments in quantifying factors causing food price inflation. World Bank Policy Research Working Paper Series.

Janssen, R., Turhollow, A. F., Rutz, D., \& Mergner, R. (2013). Production facilities for second-genration biofuels in the USA and the EU current status and future perspectives. Biofuels, Bioproducts \& Biorefining, 7, 647-665.

Kristoufek, L., Janda, K., \& Zilberman, D. (2012). Correlations between biofuels and related commodities before and during the food crisis: a taxonomy perspective. Energy Economics, 34, 1380-1391.

Kristoufek, L., Janda, K., \& Zilberman, D. (2013). Price transmission between biofuels, fuels, and food commodities. Biofuels, Bioproducts \& Biorefining, 8, 362-373.

Maddala, G. S., \& Kim, I. (1998). Unit roots, cointegration and structural change. Cambridge, UK: Cambridge University Press.

Maekawa, M., Yamamoto, T., Takeuchi, Y., \& Hatanaka, M. (1996). Estimation in dynamic regression with an integrated process. Journal of Statistical Planning and Inference, 49, 279-303.

Mitchell, D. (2008). A note on rising food prices. World Bank Policy Research Working Paper Series, http://ssrn.com/abstract=1233058.

Muller, A., Schmidhuber, J., Hoogeveen, J., \& Steduto, P. (2008). Some insights in the effect of growing bio-energy demand on global food security and natural resources. Water Policy, $10(\mathrm{~S} 1)$, 83-94.

OECD. (2008). Raising food prices: causes and consequences. Paris: OECD. www.oecd.org/trade/agricultural-trade/40847088.pdf.

Roberts, M.J., \& Schlenker, W. (2010). Identifying supply and demand elasticities of agricultural commodities: Implications for the US Ethanol Mandate. NBER Working Paper No. w15921.

Serra, T. (2013). Time-series econometric analyses of biofuel-related price volatility. Agricultural Economics, 44, 53-62.

Serra, T., \& Zilberman, D. (2013). Biofuel-related price transmission literature: a review. Energy Economics, 37, 141-151.

Serra, T., Zilberman, D., Gil, J. M., \& Goodwin, B. K. (2011). Nonlinearities in the U.S. corn-ethanol-oil-gasoline price system. Agricultural Economics, 42, 35-45.

Shaw, D. J. (2007). World food security a history since 1945. Houndsmill, UK: Palgrave MacMillan.

Tyner, W. E. (2013). Biofuels and food prices: separating wheat from chaff. Global Food Security, 2, 126-130.

Yu, T.H., Bessler, D.A., Fuller, S. (2006). Cointegration and causality analysis of world vegetable oil and crude oil prices. Selected Paper prepared for presentation at the American Agricultural Economics Association Annual Meeting, Long Beach, CA July 23-26.

Zhang, Z., Lohr, L., Escalante, C., \& Wetzstein, M. (2010). Food versus fuel: what do prices tell us? Energy Policy, 38, 445-451.

Zilberman, D., Hochman, G., Rajagopal, D., Sexton, S., \& Timilsina, G. (2012). The impact of biofuels on commodity food prices: assessment of findings. American Journal of Agricultural Economics, 95(2), 275-281.

Ziolkowska, J., Meyers, W., Meyers, S., \& Binfield, J. (2010). Targets and mandates: lessons learned from EU and US biofuels policy mechanisms. AgBioforum, 13(4), 398-412. 


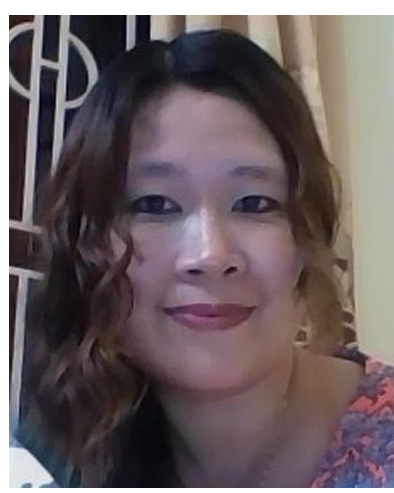

Hang To is currently a lecturer at the Crawford School of Public Policy at the Australian National University (ANU). She is working on econometric applications to problems in natural resource management, including fishery management, water allocation and use, energy and biofuels, food security, forestry, climate change and environmental issues, as well as in labour economics and commodity prices. She completed her $\mathrm{PhD}$ in Economics at the $\mathrm{ANU}$ in December 2010 and her main interest is econometrics and quantitative analyses in a wide range of research areas in applied economics.

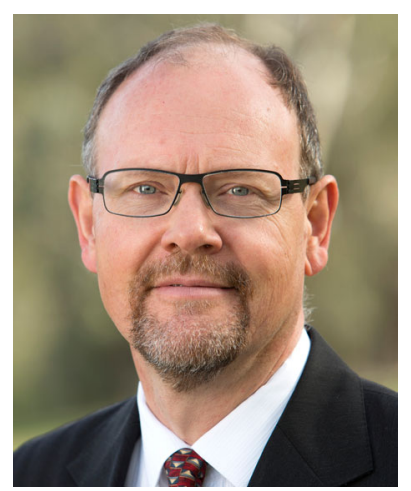

Quentin Grafton is Professor of Economics at the Australian National University (ANU). He is a Fellow of the Academy of Social Sciences of Australia (FASSA) and Chairholder, UNESCO Chair in Water Economics and Transboundary Water Governance. He is the founder of the Global Water Forum (www. globalwaterforum.org), Director of the Food, Energy, Environment and Water Network (www.fe2wnetwork.org/) and Editor in Chief of Policy Forum (www.policyforum.net/). He has served in various policy advisory roles including as the Chair of the Socio-economics Reference Group for the Murray-Darling Basin Commission (2008-2009) and is currently the Chair of the Marine Estate Expert Knowledge Panel. 